This is an Accepted Manuscript of an article published by Taylor \& Francis in Critical Asian Studies Review in March 2015, available online:

http://criticalasianstudies.org/issues/vol47/no1/contesting-tobacco-control-policy-inindonesia.html

\title{
Contesting Tobacco Control Policy in Indonesia
}

\author{
by \\ Andrew Rosser \\ University of Adelaide \\ andrew.rosser@adelaide.edu.au \\ Submitted to Critical Asian Studies
}

October 2014

Draft Only. Not for citation. 


\begin{abstract}
Over the past decade and a half, the Indonesian government has progressed fitfully and inconsistently towards a stricter tobacco control policy regime albeit without much impact on the country's worsening tobacco epidemic. The author explains this pattern of reform in terms of the unequal but changing relationship of power between tobacco companies and tobacco farmers, on the one hand, and tobacco control advocates based in NGOs, health professional organizations, universities and international organizations, on the other. The first of these coalitions has had greater structural leverage, better political connections, stronger organizational capacity, greater ability to mobilize popular forces, and more capacity to cultivate a positive public image. But the second coalition has been able to exercise some influence over policy because of changes wrought by democratization. Looking to the future, the author suggests that further progress in Indonesia's tobacco control policies will be contingent upon an ongoing process of struggle; however, there are signs that the tide is turning in favor of the second coalition.
\end{abstract}

\title{
Acknowledgements
}

I wish to thank the Australian Research Council for funding this article through grant number FT110100078 and three anonymous reviewers for their comments on an earlier draft. The usual caveat applies. 
Glossary

\begin{tabular}{|l|l|}
\hline AMTI & Indonesian Tobacco Community Alliance \\
\hline APTI & Indonesian Tobacco Farmers Association \\
\hline BAT & British American Tobacco \\
\hline DTCs & domestic tobacco companies \\
\hline FAKTA & Jakarta Citizens' Forum \\
\hline FCTC & Framework Convention on Tobacco Control \\
\hline GAPPRI & Indonesian Cigarette Manufacturers Association \\
\hline GAPRINDO & White Cigarette Producers Association \\
\hline IAKMI & Indonesian Public Health Experts Association \\
\hline ICW & Indonesia Corruption Watch \\
\hline IDI & Indonesian Doctors' Association \\
\hline IFPPD & $\begin{array}{l}\text { Indonesian Forum of Parliamentarians on Population and } \\
\text { Development }\end{array}$ \\
\hline Komnas PA & National Commission for Child Protection \\
\hline Komnas PT & National Commission for Tobacco Control \\
\hline LM3 & Institute for Preventing Smoking Problems \\
\hline MUI & Council of Indonesian Ulama \\
\hline NGO & non-governmental organization \\
\hline NU & Nahdatul Ulama \\
\hline PD & Democrat Party \\
\hline PDI-P & Indonesian Democratic Party of Struggle \\
\hline PKB & National Awakening Party \\
\hline PMI & Philip Morris International \\
\hline TCAs & tobacco control advocates \\
\hline TCSC & Tobacco Control Support Center \\
\hline TTCs & transnational tobacco companies \\
\hline WHO & World Health Organization \\
\hline WITT & Indonesian Women Against Tobacco \\
\hline YJI & Indonesian Heart Foundation \\
\hline YKI & Indonesian Cancer Foundation \\
\hline YLKI & Indonesian Consumers Foundation \\
\hline & \\
\hline
\end{tabular}




\section{Introduction}

Indonesia is in the midst of a severe and long-running tobacco epidemic. Between 1995 and 2010, the percentage of Indonesian men who smoke rose from 53 to 66 and the percentage of women who smoke rose from 1.7 to 4.2. Between 2001 and 2010, the number of children between 10 and 14 years of age who started smoking rose by 80 percent and the number who started smoking between five and nine years quadrupled. ${ }^{1}$ Annual cigarette production fell in the wake of the 1997-8 Asian economic crisis but has climbed steadily since 2003 to reach almost 250 billion in 2010. ${ }^{2}$ A staggering 78 per cent of adult Indonesians are exposed to passive smoke at home. ${ }^{3}$ Indonesia is the $43^{\text {rd }}$ biggest consumer of cigarettes in per capita terms. But in aggregate it is the fifth largest consumer and fifth largest producer of cigarettes in the world and it rates sixth in terms of the proportion of the male population that smokes. ${ }^{4}$ The health and welfare effects of this situation have been enormous: according to one recent study, smoking kills at least 200,000 Indonesians each year while also contributing to lower economic productivity through reductions in physical functioning, lung capacity, and more frequent illness. ${ }^{5}$

During the 'New Order', the authoritarian regime that ruled Indonesia from 1965 to 1998, the Indonesian government did almost nothing to combat—and virtually everything to encourage - the tobacco epidemic. Since the end of the New Order and transition to a more democratic polity, it has moved fitfully and inconsistently towards tougher tobacco control policies. On the one hand, it has imposed a range of new restrictions on tobacco marketing, sales and use and passed a law stating that tobacco is an addictive substance. On the other hand, it has backtracked on some of these reforms; refused to sign up to the World Health Organization's (WHO) Framework Convention on Tobacco Control (FCTC), the key international standard in relation to tobacco control policy; and continued to promote increased domestic tobacco production. Overall, it has produced a tobacco control policy regime that is significantly stronger than during the New Order period but still weak by FCTC standards.

In this article, I examine the political dynamics underlying this pattern of reform. Like many other developing countries, tobacco politics in Indonesia has been characterised by an unequal contest between tobacco companies and tobacco farmers, on the one hand, and

\footnotetext{
${ }^{1}$ Ministry of Health 2011.

2 Tobacco Control Support Center-IAKMI 2012, 69-70.

${ }^{3}$ World Health Organization 2012.

${ }^{4}$ Eriksen et al. 2014, 99-105.

${ }^{5}$ Barber et al. 2008.
} 
tobacco control advocates (TCAs) in NGOs, health professional organisations, universities, and international organisations, on the other. ${ }^{6}$ The first of these coalitions has exercised the dominant influence over tobacco control policy by virtue of its greater economic power, better political connections, stronger organisational capacity, greater ability to mobilise popular forces, and higher capacity to cultivate a positive public image through corporate social responsibility and philanthropic activities. I suggest, however, that the second coalition has come to exercise increasing influence over policy because of two effects of democratisation: (i) the emergence of accessible new 'policy spaces, ${ }^{7}$, particularly in relation to the parliament and court system and (ii) increased state responsiveness to concerns about tobacco consumption as a result of changes in political leadership and politicians' electoral strategies. Combined together, these effects have produced a slight shift in the balance of power that, while not enough to challenge the dominant influence of the first coalition, has created some modest possibilities for reform.

In presenting this analysis, I aim to contribute to the current debate concerning the nature of Indonesia's political economy in the post-New Order period. On one side of this debate, scholars such as Vedi Hadiz, Richard Robison, and Jeffrey Winters have argued that policy-making in post-New Order Indonesia has remained just as exclusionary as it was under the New Order despite the fact that the country has become more democratic and decentralised. ${ }^{8}$ Instead of fading from the scene, the politico-bureaucratic, business and criminal figures who dominated the New Order 'have been able to reinvent themselves through new alliances and vehicles, much like they have, for example, in parts of Communist Eastern Europe/Central Asia' ${ }^{9}$ Hadiz and Robison have also suggested that the New Order's systematic pursuit of a policy of disorganising civil society and repressing any form of political activity on the part of opposition groups has 'effectively paralys[ed] most independent capacity for self-organisation among groups like the urban middle class and the working class' ${ }^{10}$ Scholars working on the nature of regulatory governance in post-New Order Indonesia have echoed these themes, arguing that efforts to promote market reform have faltered in the face of resistance from political, bureaucratic and corporate elites with a

\footnotetext{
${ }^{6}$ Cairney et al. 2012, 166-188.

${ }^{7}$ Brock et al. 2001.

${ }^{8}$ Hadiz 2010; Hadiz and Robison 2005; Robison and Hadiz 2004; Winters 2010.

${ }^{9}$ Hadiz 2003, 593.

${ }^{10}$ Hadiz and Robison 2005, 232.
} 
vested interest in the continuation of the nationalist and patrimonial forms of economic governance that were a strong feature of New Order rule. ${ }^{11}$

On the other side of this debate, scholars such as Ed Aspinall, Marcus Mietzner and I have argued that democratization and decentralization have opened up new opportunities for groups previously excluded from the policy-making process to exercise some influence, resulting in a slightly more inclusive political system. For instance, in an early article, I argued that the shift to a more democratic political regime had (i) removed key obstacles to organization by poor and disadvantaged groups and NGO activists, making it easier for them to engage in collective action aimed at achieving pro-poor change; and (ii) created an electoral incentive for politicians to promote policy changes that benefit these groups or at least appeal to them. ${ }^{12}$ In more recent work, I have pointed to the way in which parents, teachers and their NGO allies have been able to influence education policy-making through lobbying, demonstrations, the media, and strategic use of the court system. ${ }^{13}$ Several scholars have noted that some national and local political leaders have used 'populist' policies to get themselves elected or re-elected. ${ }^{14}$ Mietzner has also drawn attention to the fact that numerous NGO activists from New Order times have become active in political parties, the legislature, and (to a lesser extent) the executive in the post-New Order period, giving them direct access to the policy-making process. ${ }^{15}$

The analysis I present here adds further ballast to the second perspective. In writing about tobacco control policies in Indonesia, many commentators have emphasised the ability of tobacco companies-both domestic and transnational-to stymie tobacco control initiatives through lobbying, deception and corruption. ${ }^{16}$ In contrast, I consider two other variables that have also influenced policy outcomes: namely i) the capacity of TCAs to gain access to the policy-making process and ii) the degree of state responsiveness to their demands. I also note the important political role played by tobacco farmers: while relatively weak compared to tobacco companies, their activism in opposing tobacco control initiatives has provided a crucial fig-leaf for the latter's interests. The overall point here is that, while tobacco companies have been a powerful influence on Indonesia's tobacco control policies in the post-New Order period, they have not been the only influence. Other actors have been

\footnotetext{
${ }^{11}$ Dick 2008; Jarvis 2012.

${ }^{12}$ Rosser et al. 2005.

${ }^{13}$ Rosser and Curnow 2014; Rosser forthcoming.

${ }^{14}$ Mietzner 2009; Rosser and Wilson 2012; Aspinall 2013; 2014.

${ }^{15}$ Mietzner 2013.

${ }^{16}$ Lawrence and Collin 2004; Hanafiah 2011; Dhyatmika 2011; Hurt et al. 2012.
} 
involved, with, in some instances, important consequences for the nature of tobacco control policy.

I also seek to contribute to the small, but growing, literature on the politics of tobacco control in developing countries. ${ }^{17}$ In general, this literature has portrayed tobacco control policy in developing countries as externally-driven. On the one hand, transnational tobacco companies have so much power and influence that they have been able to stymie any prospect of effective tobacco control reform in these countries. ${ }^{18}$ On the other hand, to the extent that progress has occurred, this has been because of 'policy diffusion' from developed countries-especially via the FCTC—rather than shifts in the balance of power between proand anti-tobacco control groups within developing countries. ${ }^{19}$ In contrast, I emphasise the importance of domestic political factors in shaping tobacco control policy. While domestic TCAs in Indonesia may have received assistance from and/or formed alliances with transnational actors, they have not been mere proxies for foreign interests and their activism has influenced policy independently of policy diffusion effects. Likewise, domestic tobacco companies have been key actors in the Indonesian context, although their interests with regards to tobacco control have been the same as transnational tobacco companies. Finally, I illustrate that the nature of domestic political institutions matters: specifically, it shows that domestic TCAs can play a more significant role in promoting tobacco control in developing countries when operating in a context of participatory policy spaces and changing elite electoral incentives than when they are excluded from policy-making under authoritarian rule. In this respect, I offer a little more hope for reform, at least in the Indonesian case, than much of the literature.

The article begins by examining the changes to Indonesia's tobacco control policy regime that have occurred during the post-New Order period. It then examines the two coalitions' policy agendas, the balance of power between them, and how this has varied over time. The final section of the article presents the conclusions and speculates on the likely future trajectory of change.

\section{Changes in Indonesia's Tobacco Control Policy Regime}

Under the New Order, the Indonesian government did almost nothing to restrict the sale, marketing or use of tobacco products. The Information Minister formally banned cigarette

\footnotetext{
${ }^{17}$ See Bump and Reich 2013 for a review.

18 Stebbins 1990; 2001; Sébrie et al. 2005.

${ }^{19}$ Cairney et al. 2012, 46, 167.
} 
advertisements in the electronic media in the early 1990s. But in practice such advertisements were widely broadcast on television throughout the country regardless of the time of day. ${ }^{20}$ Nor were there any serious restrictions on the sale or supply of cigarettes to adolescents or prohibitions on smoking in public places, although the Health Ministry itself was declared a smoke free zone. ${ }^{21}$ In 1991, the government introduced a requirement for cigarette packages to carry a written warning about the negative health effects of smoking. But it opted for a statement, 'Smoking can endanger health' (Merokok dapat merusak kesehatan), widely regarded as weak. It also did not require that this statement be accompanied by pictorial warnings. $^{22}$

At the same time, the government actively promoted the production of tobacco products, in particular, kretek, clove-scented cigarettes that were first manufactured in Kudus, East Java, in the late 1800s. ${ }^{23}$ It imposed low taxes on tobacco products, helping to keep cigarette prices low and encourage demand: indeed, according to the World Bank, Indonesia's cigarette prices actually fell in real terms during the 1980s and most of the 1990s, contributing (along with rising incomes) to an almost fourfold increase in per capita cigarette consumption between 1966 and 1996. ${ }^{24}$ Beginning in the late 1970s, the government introduced regulations to restrict mechanisation of cigarette production in an attempt to protect employment and the competitive position of small and medium-sized (mostly indigenously-owned) tobacco companies vis-a-vis large (predominantly ethnic Chineseowned) tobacco companies, the latter tending to be more mechanised. But these were never properly implemented. Driven by mechanisation, cigarette production increased from roughly 38 billion per year in 1971 to 154 billion in 1992. ${ }^{25}$ The government's establishment in 1990 of a clove monopoly controlled by President Suharto's son, Tommy, did result in a drop in cigarette production as a result of its impact on the price of cloves. However, this proved temporary; production recovered within two years. ${ }^{26}$ The government subsequently scrapped the monopoly as part of bailout negotiations with the IMF in 1997-1998.

\footnotetext{
${ }^{20}$ Widiastuti 1996; Indonesian Consumers’ Foundation 1996.

${ }^{21}$ Barraclough 1999, 328; Jakarta Post 1996.

22 Straits Times 1991; Kompas 1991a.

23 Tarmidi 1996, 86.

${ }^{24}$ World Bank 2000. The Bank shows that Indonesia's tobacco taxes were low relative to other countries in the region. The increasing affordability of tobacco products suggests that the government also kept tobacco taxes low relative to the level that would have maximised government revenues. See Guindon et al. 2003 for a detailed analysis.

${ }^{25}$ Tarmidi 1996, 88-89.

${ }^{26}$ Tarmidi 1996, 106.
} 
The fall of the New Order in 1998 saw the government's approach to tobacco control shift almost immediately. Government Regulation 81/1999 on Cigarette Control for Health imposed a series of new restrictions on the sale, marketing and use of tobacco products. For instance, it stipulated that advertising of tobacco products was prohibited in the electronic media (Article 17); was required to include a health warning (Article 20); and should not encourage people to smoke, suggest that smoking has health benefits, target children or pregnant women, include pictures of cigarettes or people smoking, or mention that the product is a brand of cigarettes (Article 18). The regulation also set maximum nicotine and tar levels for cigarettes (Article 4); imposed bans on smoking in specified public places (Article 23); prohibited the distribution of free cigarettes as a marketing exercise (Article 21); and required cigarette packages to disclose tar and nicotine content levels (Article 6) and carry a more detailed health warning —namely, that 'Smoking can cause cancer, heart attacks, impotence and harm pregnancies and fetal development' (Article 8). Finally, it imposed sanctions (fines and jail terms) for violation of advertising restrictions and failure to include health warnings (Article 37).

Some of these changes were overturned almost immediately through two subsequent government regulations. Government Regulation 38/2000, an amendment to the 1999 regulation, permitted cigarette advertising in electronic media between 9.30pm and 5.00am while Government Regulation 19/2003 on Cigarette Control for Health removed the restriction on maximum nicotine and tar levels and sanctions for violation of the regulation. At the same time, despite playing a key role in the drafting of the FCTC, the government refused to sign or ratify this agreement when it was finalized in 2003, making Indonesia one of only a small number of countries not to do so. The government has also continued to promote domestic tobacco production, providing in its 2007-2020 Roadmap of Tobacco Products Industry and Excise Policy for a 12 per cent increase in cigarette production between 2000 and 2020. ${ }^{27}$ To this end, it has set tobacco taxes at a level below neighbouring countries such as Singapore and Thailand and the maximum level permitted under the 2007 Law on Excise Duties. ${ }^{28}$

The 2009 Health Law shifted the pendulum slightly back in favor of tobacco control. Article 113 explicitly identified tobacco as an addictive substance, something the previous (1992) Health Law had not done. Article 114 reinforced earlier requirements for cigarette packages to contain a health warning while noting in the corresponding part of the

\footnotetext{
${ }^{27}$ Hurt et al. 2012, 310.

${ }^{28}$ Tobacco Control Support Center-IAKMI 2012, 98.
} 
Elucidation to the Law that this warning could (dapat) incorporate a pictorial element. Article 115 stipulated that certain places would be 'Smoke Free Areas' including schools, hospitals, health centers, and playgrounds; required regional governments to implement this policy in their respective regions; and (again in the corresponding part of the Elucidation) stated that 'workplaces, public places and other places' could provide special areas for smokers. Over the following few years, most of these provisions were challenged in the Constitutional Court with outcomes that varied in terms of the tobacco control agenda. On the one hand, the Court defended the identification of tobacco as an addictive substance and ruled that cigarette packages must contain pictorial warnings along with the written one. On the other hand, it decided that 'workplaces, public places and other places' must provide special smoking areas, giving smokers the right to smoke indoors in designated places. ${ }^{29}$

Government Regulation 109/2012 on Control of Substances that Contain Addictive Chemicals in the Form of Tobacco Products for Health took things a step further, prohibiting false and misleading packaging and labeling (such as use of the terms 'mild' and 'light' to describe tobacco products) (Article 24) and providing for the implementation of pictorial warnings and smoke free places (Articles 14 and 49) (Pictures 1-3 show a selection of the pictorial warnings approved by the government for introduction in April 2014). It also imposed new restrictions on tobacco company sponsorship of music concerts and sporting events including a ban on the use of company or product logos and brands (including brand images) in sponsorship material at these events and a ban on tobacco company sponsorship of events covered by the media (Articles 35-37). However, another key tobacco control initiative-a dedicated tobacco control law initially proposed as a parliamentary member's bill in 2006-was defeated around this same time. It has been replaced in the parliamentary legislative agenda by a draft Tobacco Law sponsored by the tobacco industry. At the time of writing (August 2014), this was being debated within the parliament, indicating the potential for another round of backtracking on tobacco control reform. ${ }^{30}$

\section{INSERT PICTURES 1-3 AND ASSOCIATED CAPTION HERE}

In sum, then, the overall effect of the aforementioned policy changes has been to produce a tobacco control policy regime that is both lenient by international standards and significantly stronger than during the New Order period. It does not incorporate certain key

\footnotetext{
${ }^{29}$ Mahkamah Konstitusi 2011a; 2011b; 2012.

${ }^{30}$ Indonesia Corruption Watch nd; Hidayat et al. 2013.
} 
elements of the FCTC: most notably, (i) a comprehensive ban on tobacco advertising, promotion and sponsorship, enabling tobacco companies to promote their products with some freedom (see Pictures 4-8); and (ii) restrictions on the sale of individual cigarettes (something that is necessary to limit sales of tobacco products to children and the poor). And it continues to favor increased domestic tobacco production. But it imposes constraints on tobacco marketing, sales and use that were not in place during the New Order period and which are generally consistent with the FCTC. Current efforts to enact a dedicated Tobacco Law may see the relaxation or removal of some of these constraints but this remains to be seen.

\section{INSERT PICTURES 4-8 AND ASSOCIATED CAPTION ABOUT HERE}

\section{The Competing Coalitions}

This pattern of tobacco control policy reform has been the outcome of a struggle between two competing coalitions, the first consisting of tobacco companies and farmers and the second consisting of TCAs in NGOs, health professional organisations, and international organisations. Below I examine the composition of these coalitions and their respective policy agendas.

\section{Tobacco Companies and Farmers}

In most developing countries, the tobacco industry has been dominated by transnational tobacco companies (TTCs) such as Philip Morris International (PMI), Rothmans, and British American Tobacco (BAT) and, in some cases, state-owned tobacco companies. ${ }^{31}$ In Indonesia, however, it has been private domestic tobacco companies (DTCs) that have historically been the dominant element in the tobacco industry, with the 'big four' — Gudang Garam, Djarum, Sampoerna and Bentoel-being particularly important in this respect. ${ }^{32}$ In the late 1990s, these four companies collectively accounted for around 85 per cent of cigarette sales. $^{33}$ In 2005 PMI purchased Sampoerna ${ }^{34}$ and in 2009 BAT purchased Bentoel, giving the two TTCs a much larger slice of Indonesia's cigarette market and, in so doing, transforming it into one with greater balance between DTCs and TTCs. ${ }^{35}$ The current ranking

\footnotetext{
${ }^{31}$ Cairney et al. 2012, 167.

${ }^{32}$ Lawrence and Collin 2004.

${ }^{33}$ Reynolds 1998.

${ }^{34}$ The Sampoerna family retained a 5 per cent minority shareholding in the company. See PT Data Consult Inc. 2009.

${ }^{35}$ Hurt et al. 2012.
} 
of the big four by market share is: PMI/Sampoerna (29 percent of cigarette sales), Gudang Garam (21 percent), Djarum (19 percent), and BAT/Bentoel (8 percent). ${ }^{36}$

Regardless of tobacco companies' status in terms of the DTC/TTC divide, they have consistently opposed tobacco control initiatives-such as increased tobacco taxation; restrictions on cigarette advertising, sponsorship and promotion; and tougher health warnings on cigarette packages — on the grounds that these measures would have a negative impact on government taxation revenues and employment and livelihood opportunities for poor people in tobacco growing and cigarette producing areas. ${ }^{37}$ Before the takeovers, DTCs and TTCs had somewhat different interests and agendas in relation to tobacco taxation, reflecting the fact that the government taxed kretek (of which DTCs were then the major producers) and white cigarettes (of which TTCs have been the major producers) at different rates, imposing lower taxes on the former than the latter. ${ }^{38}$ But because these takeovers have given PMI and BAT a much stronger presence in the kretek market segment than previously, these interests are no longer as distinct.

In pursuing their agenda, tobacco companies have forged a strategic alliance with tobacco farmers from major tobacco growing areas such as Kudus, East Java, and Temanggung, Central Java, particularly since the transition to democracy when it has become politically expedient for the tobacco companies to align themselves with popular forces. Through representative associations such as the Indonesian Tobacco Farmers Association (APTI), established in 2000, tobacco farmers have echoed tobacco companies' concerns about the potentially negative effects of tobacco control on government taxation revenues and poor people's employment and livelihoods. ${ }^{39}$ Both tobacco companies and tobacco farmers have also raised the spectre of foreign domination of the tobacco industry, arguing that tobacco control will be particularly damaging to kretek production because these cigarettes have relatively heavy concentrations of ingredients that are damaging to people's health. ${ }^{40}$ They have also suggested that, with smoking being such a widespread and accepted practice in Indonesia, greater tobacco control represents a threat to Indonesian culture. ${ }^{41}$ Tobacco farmers are a highly differentiated group in socio-economic terms and are led by their wealthier elements. ${ }^{42}$ For instance, one of the key actors within the group in relation to

\footnotetext{
36 Tobacco Control Support Center-IAKMI 2012, 72.

${ }^{37}$ Reynolds 1998; Lawrence and Collin 2004; Hurt et al. 2012.

38 Tarmidi 1996.

${ }^{39}$ Nugroho 2008; Jakarta Globe 2012.

${ }^{40}$ Harian Terbit 2013.

${ }^{41}$ Mahkamah Konstitusi 2009.

${ }^{42}$ I wish to thank one of the anonymous reviewers for advice on this point.
} 
tobacco control issues, Bambang Sukarno, is a plantation owner and the chairperson of the Temanggung regional parliament. ${ }^{43}$

\section{Tobacco Control Advocates}

Indonesia's TCAs are a small but diverse group of individuals consisting of at least five distinct sub-groups. The first is activists at NGOs with strong elite connections such as the Indonesian Heart Foundation (YJI) and the Indonesian Cancer Foundation (YKI). Established in the 1970s, these two organisations have both been dominated by women married to or otherwise associated with senior government officials and business people. For instance, YJI's leading figures have included Nyonya D. Bustanil Arifin (the wife of Bustanil Arifin, the former head of the National Logistics Agency) and Laksmiati Hanafiah (the wife of Indonesia's first professor of cardiology at the University of Indonesia and sister of the chairman of the Indonesian Chamber of Commerce and Industry) while YKI's leading figures have included Ibu Karlinah Umar Wirahadikusuma (the wife of Umar Wirahadikusuma, the former head of the state audit agency and Vice President of Indonesia from 1983-1988), Adiati Arifin Siregar (wife of former central bank governor Arifin Siregar), and Prof. Dr. Nila Moeloek (an academic who is the wife of Farid Anfasa Moeloek, a former Minister of Health under Suharto and Habibie). Another organisation in this group is Indonesian Women Against Tobacco (WITT) which was established in 1996 by Tuti Roosdiono, a local painter and the wife of a prominent commercial lawyer. ${ }^{44}$ While the details are unclear, these organisations all appear to be well-funded by NGO standards, presumably attracting donations from wealthy Indonesian citizens. YJI and YKI's premises in the leafy Jakarta suburb of Menteng, for instance, were both donated by Bustanil Arifin. ${ }^{45}$

The second sub-group are activists based at other NGOs. The most important of these organisations have been the Indonesian Consumers Foundation (YLKI), the Jakarta Citizens' Forum (FAKTA), the Institute for Preventing Smoking Problems (LM3), Indonesia Corruption Watch (ICW) and the National Commission for Child Protection (Komnas PA). With the exception of YLKI, these organisations were all founded early in the post-New Order period. YLKI has arguably been the most active organisation within this sub-group in terms of engagement with tobacco control advocacy. Founded in the 1970s, it was initially funded by Ali Sadikin, the Governor of Jakarta and run, like YJI and YKI, by women from

\footnotetext{
${ }^{43}$ Tempo 2009.

${ }^{44}$ Kompas 1996.

${ }^{45}$ Interview with Laksmiati Hanafiah, Jakarta, November 2013.
} 
elite backgrounds. But through a process of generational change, it has become increasingly independent of this social stratum. ${ }^{46}$ All these NGOs have looked to Indonesia's middle classes and international donors and NGOs for funding and political support, with the Bloomberg Initiative being a particularly important source of funding for their tobacco control activities since 2007 when it provided grants to, among others, ICW, FAKTA, and Komnas PA. ${ }^{47}$ In the case of YLKI and LM3, however, tobacco control activism goes back well before this time, in both cases to at least the mid-1980s.

The third sub-group are health professionals associated with representative organisations such as the Indonesian Doctors Association (IDI) and the Indonesian Public Health Experts Association (IAKMI). IDI and IAKMI have historically engaged in relatively little advocacy work on tobacco control issues in their own right. IDI did some lobbying on these issues in the late 1980s and early 1990s and again in the late 2000s but otherwise has focused on issues such as foreign doctor entry into Indonesia and doctor malpractice. ${ }^{48}$ IAKMI only became active in relation to tobacco control in 2007, when it received funding from the Bloomberg Initiative to establish the Tobacco Control Support Center (TCSC), a facility to provide information and data on tobacco control issues and lead key advocacy campaigns. ${ }^{49}$ However, some of these organisations' most prominent members-Kartono Muhammad, Prijo Sidipratomo (both former heads of IDI), and Widyastuti Soerojo (former head of the TCSC) — have been among Indonesia's leading voices on tobacco control and, at least in Kartono's case, active in this respect since the late 1980s.

The fourth sub-group are public health, demography and economics researchers at the University of Indonesia, particularly its Faculty of Public Health and Demography Institute. With funding provided through academic, policy and NGO networks, they have played a key role in producing the evidence required to support TCAs' arguments in favour of tobacco control, particularly with regards to the health and economic impacts of the tobacco industry. ${ }^{50}$

The fifth sub-group are officials at the WHO and other international organisations concerned about Indonesia's tobacco epidemic such as the World Bank. The WHO has been active in relation tobacco control issues since at least 1975 when it established the first expert

\footnotetext{
${ }^{46}$ Kinasih 2011, 54-63.

${ }^{47}$ Bloomberg Initiative nd.

${ }^{48}$ Interview with Kartono Muhammad, former head of IDI, Jakarta, November 2013.

${ }^{49}$ Bloomberg Initiative nd.

${ }^{50}$ See, for instance, Thabrany and Sarnantio 2012; Ahsan et al. 2010; and Achadi et al. 2005.
} 
committee on smoking and its effects on health ${ }^{51}$ but particularly so since 1998 when it made tobacco control one of its main priorities. The World Bank has been much less engaged with tobacco control issues but has offered the WHO crucial political and analytical support, ${ }^{52}$ publishing a major report in 1999 that outlined an economic case for greater tobacco control. ${ }^{53}$ In the Indonesian context, the WHO has sought to promote tobacco control from behind-the-scenes, ${ }^{54}$ although some officials have occasionally made public calls for stricter tobacco control measures. ${ }^{55}$

Broadly speaking, TCAs in these five sub-groups have shared the same policy agenda. Some NGOs have had a particular focus to their activism: for instance, Komnas PA has focused on youth smokers, FAKTA on the Jakarta context, and ICW on alleged corruption by tobacco companies. But they have all broadly supported tougher restrictions on tobacco advertising, promotion, and use; reduced tobacco production; and ratification of the FCTC. ${ }^{56}$

\section{The Changing Balance of Power}

Of these two coalitions, the first has exercised much greater influence over tobacco control policy during both the New Order and post-New Order periods for five reasons. First, the tobacco companies have had much greater structural leverage ${ }^{57}$ over the state than TCAs. With cigarette production and consumption growing exponentially since the 1960s, tobacco companies have become major investors, employing large workforces, paying substantial government taxes, and stimulating significant economic activity in other sectors such as the media, sport, retail and hospitality. Even on TCAs' figures, tobacco companies accounted for 6.4 per cent of total government revenues in 2010 and employed over 600,000 farmers and 330,000 factory workers in 2009. ${ }^{58}$ This has meant a significant economic cost for the government in implementing tobacco control policies that produce a reduction in tobacco consumption and production. On the TCAs' side, the World Bank and the WHO have had some structural leverage over the state by virtue of their ability to withhold loans or grants to the Indonesian government. But it is not clear that they have been willing to exercise it and,

\footnotetext{
${ }^{51}$ Cairney et al. 2012, 50.

${ }^{52}$ Chorev 2013.

${ }^{53}$ World Bank 1999.

${ }^{54}$ Interview with a WHO official, Jakarta, November 2013.

55 Jakarta Post 1995.

${ }^{56}$ See Widiastuti 1996 and Chamim et al. 2011 for statements outlining TCAs’ policy agenda.

${ }^{57}$ Structural leverage is the power that stems from having discretionary control over investment resources. See Winters 1996, 1.

${ }^{58}$ Tobacco Control Support Center-IAKMI 2012, 47, 74, 101.
} 
in any case, the extent of their leverage has paled in comparison to that of the tobacco companies.

Second, the tobacco companies have cultivated stronger connections than TCAs to senior political and bureaucratic figures and the major political parties. During the New Order period, Gudang Garam founder, Susilo Wonowidjojo, formed a joint venture with Probosutejo, Suharto's half-brother, to produce cigarette paper, in so doing cultivating a link to the first family. ${ }^{59}$ Several commentators have pointed to a close relationship between Susilo Bambang Yudhoyono (Indonesia's President from 2004-2014) and the Sampoerna Group, noting that the group’s boss, Putera Sampoerna, regularly visited the presidential palace in 2005; that Yudhoyono's son has an office in one of the group's buildings; and that the group financed the establishment of a pro-Yudhoyono newspaper. ${ }^{60}$ Although evidence is scarce, it is widely believed that the tobacco companies lobby politicians and bureaucratic officials heavily behind closed doors and have been a key source of campaign finance for many politicians and political parties, in particular those that have support bases in tobacco growing areas such as the Indonesian Democratic Party of Struggle (PDI-P), the National Awakening Party (PKB) and the Democrat Party (PD). ${ }^{61}$ The tobacco companies have done nothing to deny this.

By contrast, YJI and YKI's connections to high-level political and bureaucratic figures have been less consequential. In an interview, one source suggested-only halffacetiously - that these organisations were established to give particular elite women something to do while their husbands engaged in more important political, bureaucratic and business activities. ${ }^{62}$ This view arguably underestimates the extent of genuine concern within some parts of the Indonesian elite about the health and economic effects of the country's tobacco epidemic. But it does illustrate the very different (and arguably weaker) type of connection they have had to senior political and bureaucratic officials compared to the major tobacco companies.

Third, the tobacco companies have been better able to organise for collective action aimed at influencing government policy. The peak industry associations for cigarette producers - the Indonesian Cigarette Manufacturers Association (GAPPRI), in which DTCs have historically been the dominant element, and the White Cigarette Producers Association

\footnotetext{
${ }^{59}$ Lawrence and Collin 2004, ii97.

${ }^{60}$ Aditjondro 2010: Tampubolon 2010; Harsono 2011.

${ }^{61}$ Interviews with Tulus Abadi, YLKI, and Laksmiati Hanafiah, YJI, Jakarta, November 2013. See also Kurniawati and Rachman 2010; Hanafiah 2011; Sumartono et al. 2012.

${ }^{62}$ Interview, Jakarta, November 2013.
} 
(GAPRINDO), in which TTCs have historically been the dominant element-have been crucial in this respect. The two created a formal alliance in 1991 by establishing a joint action team on smoking and health issues and jointly opposed proposed regulatory changes in 1992 that recognised tobacco as an addictive substance. ${ }^{63}$ They have continued to collaborate closely in the post-New Order period, jointly lobbying the government against ratification of the FCTC ${ }^{64}$ and the proposed tobacco control law. ${ }^{65}$ In 2009, they also jointly established the Indonesian Tobacco Community Alliance (AMTI) in conjunction with tobacco farmer and worker groups to act as a lobby group representing all groups opposed to tobacco control. ${ }^{66}$

By contrast, TCAs have been fragmented. During the New Order period, they were hampered by the government's strategy of disorganising civil society and promoting government-controlled corporatist organisations as the principal mechanism for representation of social interests. ${ }^{67}$ In 1998, following the fall of the New Order, they established the National Commission for Tobacco Control (Komnas PT) to coordinate their various activities. But this organisation has been limited by a lack of formal authority over its (currently 23) members, modest resources, and the fact that member organisations have had different foci (anything from consumer affairs to various specific health issues) and different strategies for promoting tobacco control. With respect to the latter, a key problem has been differences over the extent to which TCAs are prepared to directly challenge the government in court. Some NGOs—such as YLKI and Komnas PA-have taken a confrontational approach. But others-most notably YJI and YKI—-have preferred to focus on educational activities, sponsorship of the WHO's 'World No Tobacco Day', and gentle lobbying of government behind the scenes, although they have participated in a number of court cases against tobacco companies and tobacco farmers. ${ }^{68}$ The consequence has been that some legal endeavours to promote tobacco control have been poorly supported. Perhaps the best example in this respect is a series of court cases led by YLKI since 2009 challenging the government's decision not to ratify the FCTC. YJI and YKI did not participate in these cases. ${ }^{69}$

Fourth, the tobacco companies' alliance with tobacco farmers has meant that they have been able to mobilise popular forces in support of their agenda. According to

\footnotetext{
${ }^{63}$ Lawrence and Collin 2004, ii97; Hurt et al. 2012, 308.

${ }^{64}$ GAPPRI 2000; Khamdi 2014.

65 Jakarta Post 2009.

${ }^{66}$ Sumut Pos 2010.

${ }^{67}$ Robison and Hadiz 2004, 120-144.

${ }^{68}$ For instance, both organisations were involved in the unsuccessful 2002 case related to the timing of cigarette advertisements mentioned below.

${ }^{69}$ Gresnews 2011.
} 
Dhyatmika, tobacco companies have provided funding to APTI to hold demonstrations, citing a specific example of a protest in Jakarta in $2010 .^{70}$ They have also allowed tobacco farmer groups to take the lead in public debates and court cases. ${ }^{71}$ Such moves have given greater legitimacy to the tobacco companies' cause by associating it with the interests of a predominantly indigenous and lower class group, in turn allowing them to deflect criticism that their opposition to tobacco control is purely self-serving and promotes ethnic Chinese/foreign economic domination. The alliance with tobacco farmers has also helped to mobilise figures associated with other organisations that have a strong base in tobacco growing areas, most notably Nahdatul Ulama (NU), one of Indonesia's two main Islamic social organisations. While Muhammadiyah (the other main Islamic social organisation) and the Council of Indonesian Ulama (MUI) have both declared smoking haram (forbidden) (in the latter's case only for children and pregnant women and in public spaces), NU has determined that it is merely makruh (something to be avoided but not necessarily sinful). ${ }^{72}$ At the same time, NU's Agricultural Development Institute has challenged tobacco control reform through the Constitutional Court. ${ }^{73}$

By contrast, TCAs have had few links to popular forces. One reason for this has been the enormous difficulty of organising 'victims of smoking' (korban rokok) given their often weak health and limited life expectancy. Another has been the nature of TCAs' geographic, political and social base. Many of the NGOs and other organisations involved in the tobacco control movement are based in Jakarta and led by university educated people from elite or middle class backgrounds with little experience in mobilising the masses. There has thus been some distance between these organisations and the communities they aim to represent, a pattern that, as Antlöv et al. have noted, is characteristic of Indonesia's NGO movement in general. $^{74}$

Finally, tobacco companies have successfully built a positive public image of themselves through corporate social responsibility and philanthropic activities. Funded in some cases by company-linked charitable foundations (e.g. the Djarum Foundation and the Sampoerna Foundation), these activities have included programmes supporting education and

\footnotetext{
${ }^{70}$ Dhyatmika 2011, 160. See also Jakarta Post 2009.

${ }^{71}$ The major tobacco companies provided written testimony at a 2010 Constitutional Court case brought by a group of tobacco farmers, but this was at the insistence of the Court itself rather than the initiative of the tobacco companies, indicating a strategy of staying in the background while tobacco farmers prosecute the fight in public. Interview with Tulus Abadi, Jakarta, November 2013.

72 Ulum 2010; Gunanto and Junaidy 2010; Taufiq 2010.

${ }^{73}$ Case No. 24/PUU-X/2012.

${ }^{74}$ Antlöv et al. 2006, 155.
} 
research; disaster relief; and sponsorship of sporting, music, arts and cultural events. ${ }^{75}$ So extensive are these activities that the tobacco industry has become a crucial underpinning of the social, cultural and sporting life of the country. ${ }^{76}$ By contrast, as noted above, TCAs are relatively weakly embedded in the wider community.

Despite their relative weakness, however, TCAs have been able to exercise greater influence over policy in the post-New Order period than they did in the New Order period as a result of two changes wrought by democratisation. The first has been the emergence of new policy spaces $^{77}$ that have been accessible to civil society groups, particularly within the country's parliament and court system. The second has been increased state responsiveness to TCAs' concerns as a result of the initial change in political leadership following the fall of Suharto and the growing political salience of health insurance programs for the poor. Below, we examine in turn each of these changes and their effects with regards to tobacco control policy.

\section{Emerging Policy Spaces}

During the New Order period, policy-making was essentially a closed process carried out within the executive arm of government. While the national parliament had formal authority to pass laws, it generally acted as a rubber stamp for drafts prepared by government ministers and their bureaucratic subordinates: genuine parliamentary debate or opposition to government was rare. Almost no government bills were ever rejected. ${ }^{78}$ The executive also prepared lower level regulations required to implement laws, some of which introduced new provisions not included in (and sometimes contradicting) the original laws. Controls on freedom of expression and organisation meant that there was generally little public debate prior to the introduction of new laws and regulations while judicial subordination to political authority and limited powers of judicial review - the Supreme Court had the authority to review regulations but not laws-ensured that there was little scope for civil society groups to challenge government laws and regulations through the courts. ${ }^{79}$

\footnotetext{
${ }^{75}$ Southeast Asia Tobacco Control Alliance 2008.

${ }^{76}$ I wish to thank one of the anonymous reviewers for this point.

${ }^{77}$ I define 'policy spaces', following Brock et al. 2001, 7, as 'sites in which different policy discourses and policy actors interact'.

78 Schwarz 1994, 272; Hariyanti and Lindsey 2006; Ziegenhain 2008, 45-77. The parliament did, however, become a little more independent and critical of government during the late decade of the New Order. See Datta 2002.

79 Thoolen 1987; Pompe 2005.
} 
Democratisation, however, has opened up a range of new policy spaces for civil society groups. Parliamentary and public debates over new laws and regulations are now commonplace, reflecting the increased authority of the national parliament and the removal of restrictions on freedom of expression and organisation. The national parliament now regularly holds public consultations during legislative processes, giving civil society groups an opportunity to provide input into the formulation of new laws. Several new state agencies, commissions and committees have been established at the national level in areas such as human rights (the National Commission on Human Rights), poverty (National Team for Accelerating Poverty Reduction), public services (the national ombudsman), and corruption (the Anti-Corruption Commission), some of which have included former civil society activists among their senior staff (e.g. the national ombudsman and the National Human Rights Commission). Former civil society activists have also increasingly penetrated the political parties, giving them an increased role in party rooms and parliamentary commissions beyond the ability to present views at public hearings. ${ }^{80}$ The media has become an important forum for public debate over policy issues and has provided groups that are able to access the media with an opportunity for to shape public opinion in their favour.

Arguably the most important new policy space to emerge since the fall of the New Order, however, has been the Constitutional Court. Established in 2003, this Court has been invested with the authority to review the constitutionality of national laws, a power that, as noted above, was not granted to any court under the New Order. The Constitutional Court has benefited from judicial selection and funding arrangements that have enhanced its autonomy from the government, the Supreme Court, and more generally the 'judicial mafia' that runs the country's court system. Most of its judges have-at least until recently-had a reformist orientation that has embraced a concern with not just civil and political rights but also socioeconomic ones. ${ }^{81}$ This in turn has created a potentially effective legal pathway through which citizens and civil society activists have been able to challenge government policies they believe infringe human rights, namely judicial review of laws. At the same time, other legal innovations such as citizen law suits, class actions, and legal standing (all of which were rare, if not unheard of, during the New Order period) have opened up new ways for civil society

\footnotetext{
${ }^{80}$ Mietzner 2013.

${ }^{81}$ Mietzner 2010; Dressel and Mietzner 2012. The Constitutional Court's reformist credentials were tarnished by revelations in 2013 that Akil Mochtar, then Chair of the court, had taken bribes in relation to a series of regional election disputes. He was sentenced to life imprisonment in June 2014.
} 
activists to engage with general courts beyond pre-existing mechanisms such as judicial review of regulations. ${ }^{82}$

TCAs have made extensive use of these new policy spaces. For instance, they actively lobbied the parliamentary commission responsible for health affairs (Commission IX) during its deliberations over the 2009 Health Law to have tobacco recognised as an addictive substance, exploiting in particular opportunities to participate in public hearings and the fact that some TCAs acted as expert staff (staf ahli) for the commission or its party fractions. They also invited parliamentary members to public seminars and interacted with them through informal meetings. Activists from several NGOs and professional organisations were involved in these processes including IDI, IAKMI, YLKI, YJI, and YKI as well as academics from the University of Indonesia. ${ }^{83}$ In prosecuting their cause, TCAs were aided by the fact that members of parliament associated with the Indonesian Forum of Parliamentarians on Population and Development (IFPPD)—a grouping of parliamentarians established in 2001 to engage with a wide range of population-related issues (including health) and supported by the Bloomberg Initiative-were sympathetic to their cause and represented in Commission IX (most notably via Dr. Hakim Sorimuda Pohan, a Deputy Chairman of IFPPD). ${ }^{84}$ The result was an effective alliance between TCAs and these members of parliament. Parliamentary transcripts indicate that early drafts of the law submitted by the Health Ministry did not contain a provision explicitly recognising tobacco as an addictive substance. ${ }^{85}$ The initiative for including one came from Commission IX, reflecting the ability of TCAs and their parliamentary allies to persuade members of Commission IX that this was necessary.

Following parliament's passage of the law, it was revealed that the relevant provision had 'disappeared' from the law before it was signed by the President. TCAs and their parliamentary allies exposed this change, exploiting links that some activists had to the media and the opportunity to frame the issue as a corruption scandal involving the tobacco companies. ${ }^{86}$ With the changes to the law exposed, President Yudhoyono was forced to call for the missing provision to be reinserted. According to Hurt et al., the tobacco industry had successfully prevented an earlier attempt to recognise tobacco as an addictive substance in

\footnotetext{
${ }^{82}$ Gatot 2007; Rosser forthcoming.

83 Interview with Hasbullah Thabrany (Professor of Public Health at the University of Indonesia), Jakarta, August 2014.

${ }^{84}$ See Asian Forum of Parliamentarians on Population and Development nd for a description of IFPPD's aims and objectives. See also Jakarta Post 2007 and Bloomberg Initiative nd.

${ }^{85}$ See, for instance, Dewan Perwakilan Rakyat 2007.

${ }^{86}$ Tempo 2009; 2010a; 2010b.
} 
the early 1990s through a direct 'approach' to government bodies. ${ }^{87}$ While cigarette companies and tobacco farmers also lobbied parliament intensively during the drafting of the 2009 Health Law ${ }^{88}$ - for instance, moves to delete the provision were triggered by a letter from Bambang Sukarno and Wisnu Broto, the head of the Central Java Clove and Tobacco Farmers' Association, threatening mass demonstrations if the provision remained in the law ${ }^{89}$ - they failed in the changed political circumstances of the post-New Order period.

TCAs have also made extensive use of the court system to promote tobacco control reform. In 2002 a group of NGOs lodged a legal standing case at the South Jakarta District Court against Sampoerna, Djarum and a range of media outlets and advertising firms over the alleged broadcast of cigarette advertisements outside officially permitted hours. ${ }^{90}$ In 2009 Komnas PA lodged a Constitutional Court challenge to provisions in the 2002 Broadcasting Law permitting cigarette advertising. ${ }^{91}$ Finally, as noted above, YLKI has led a series of court cases aimed at challenging the government over non-ratification of the FCTC. While these efforts all proved unsuccessful in terms of securing favourable court decisions-in the FCTC cases, only so far given that, at the time of writing, a final decision from the Supreme Court is still pending - they have served to raise public awareness of the policy issues to which they related. ${ }^{92}$

TCAs have been more successful in gaining favourable court decisions when they have appeared as 'third parties' (pihak terkait) in Constitutional Court cases initiated by tobacco farmers and their allies aimed at challenging legislated tobacco controls-in particular, those provided for in the 2009 Health Law. As third parties, they were able to present evidence and testimony to challenge arguments in favour of removing tobacco controls. It was this defensive endeavour, for instance, that led to the aforementioned Constitutional Court decisions confirming that tobacco is an addictive substance and ruling that cigarette packages must contain pictorial warnings along with a written one. These decisions were made in cases led, on the tobacco farmer side, by Bambang Sukarno and APTI respectively.

Notably, TCAs have not yet pursued a class action suit against tobacco companies, a move that has been part of tobacco control activism in several other countries. In interviews, two leading TCAs indicated that they were working on such a suit but it had been held up

\footnotetext{
${ }^{87}$ Hurt et al. 2012, 308.

${ }^{88}$ Interview with Hasbullah Thabrany, Jakarta, August 2014. See also Tempo 2009.

${ }^{89}$ Tempo 2010b.

${ }^{90}$ Kompas 2002.

${ }^{91}$ Mahkamah Konstitusi 2009.

${ }^{92}$ Interview with Arist Merdeka Sirait, Komnas PA, Jakarta, November 2013.
} 
because of difficulties in assembling the detailed material required for this type of lawsuit. ${ }^{93}$ Studlar argues that lawsuits can be advantageous to tobacco companies because they 'inevitably take time, and tobacco companies have huge resources to fight such suits, even if they cannot win them all'. ${ }^{94}$ In this respect, TCAs' strategy of focusing on court cases that promote policy change rather than secure damages has made a lot of sense: while it has had little impact on tobacco companies' finances, it has served to promote relatively quick change in the country's policies.

\section{Increased State Responsiveness}

The Health Ministry has, generally speaking, sided with the TCAs since at least the late 1980s, reflecting the fact that this Ministry has been dominated by health professionals, in particular ones associated with IDI and IAKMI. Almost all Ministers of Health during this period have publically expressed support for tobacco control: Adyatama (Minister of Health from 1988-1993), Sujudi (1993-1998), Farid Anfasa Moeloek (1998-1999), Achmad Suyudi (1999-2004), Endang Rahayu Sedyaningsih (2009-2012) and Nafsiah Mboi (2012-present). The main exception was Dr. Siti Fadilah Supari (Minister of Health between 2004 and 2009), a populist politician who viewed the WHO with suspicion because of its controversial management of bird flu virus strains provided by developing countries. Souring relations between the Health Ministry and the WHO during her term as Minister translated into little Ministry support for WHO initiatives including ones aimed at promoting greater tobacco control. $^{95}$

But while TCAs have generally gained support from the Health Ministry, they have encountered strong opposition from the industry, trade, and finance ministries, parts of the government more closely linked to business and industry. For these ministries, the priorities have been promoting increased government revenues, economic growth and employment, not addressing tobacco's impact on health. At the same time, as noted above, the tobacco companies appear to have cultivated strong links to the major political parties (especially the PDI-P and PKB which have their political bases in tobacco-growing areas) and many senior politicians. It was the PKB’s then leading figure and Indonesian President from 1999 to 2001, Abdurrahman Wahid, who signed Government Regulation 38/2000, watering down the 1999 regulation; and the PDI-P’s leader and Indonesian President from 2001 to 2004, Megawati

\footnotetext{
${ }^{93}$ Interviews with Arist Merdeka Sirait, Komnas PA, and Tulus Abadi, YLKI, Jakarta, November 2013. On the procedural and evidential requirements of class action suits in the Indonesian context, see Santosa 2007, 6-7. ${ }^{94}$ Studlar 2002, 269.

95 Interview with a WHO official, Jakarta, November 2013. See also Abadi 2008.
} 
Sukarnoputri, who signed Government Regulation 19/2003, watering things down further. Both of these parties have also strongly opposed the proposed tobacco control bill and government ratification of the FCTC. ${ }^{96}$

Two factors, however, have increased state responsiveness to TCAs' cause during the post-New Order period. The first was Habibie's accession to the presidency in May 1998. According to a number of TCAs, Habibie was sympathetic to the tobacco control agenda, possibly because his late wife was a doctor. ${ }^{97}$ Media reports suggest that the Health Ministry was drafting anti-smoking regulations as early as mid-1997. ${ }^{98}$ But it was only once Habibie became President that a clear window of opportunity to have these enacted emerged. According to Achadi et al., the Minister of Health, Farid Anfasa Moeloek, took advantage of Habibie's support to 'initiate' the establishment of a National Communication Forum bringing together NGOs working on tobacco issues with government staff and to push for a new tobacco control regulation. ${ }^{99}$ With the process of formulating the FCTC only just getting under way at this time, ${ }^{100}$ these changes were primarily the product of a shift in Indonesia's domestic political economy rather than policy diffusion from international sources. ${ }^{101}$ Habibie only served as President until October 1999 but he was there long enough to see Government Regulation 81/1999 through to enactment. He signed it into force on 5 October 1999.

The second factor has been the growing political salience of health insurance schemes for the poor during the post-New Order period. The transition to democracy has created strong incentives for politicians to promote pro-poor social programs as a way of mobilising votes from Indonesia's poor. In 2004, for instance, current President Susilo Bambang Yudhoyono introduced Askeskin (subsequently relaunched in 2008 as Jamkesmas after a few administrative changes), a program that provided poor people with free care at public health facilities and participating private facilities. Similar programs have been introduced at the district level. ${ }^{102}$ The introduction of these programs — coupled with the national government's decision to provide universal health coverage to Indonesian citizens from 2014—has created

\footnotetext{
96 Jakarta Post 2009; Chamim 2011, 177; Aritonang 2012; Republika Online 2014.

${ }^{97}$ Interviews with Laksmiati Hanafiah, Jakarta, November 2013 and Hasbullah Thabrany, Jakarta, August 2014. See also Hanafiah 2011, 81.

98 Jakarta Post 1997.

99 Achadi et al. 2005, 337.

100 The World Health Assembly requested the WHO Director-General to prepare a Framework Convention on Tobacco Control in 1996. But it was not until late October 1999 that the FCTC Working Group met to carry out preparatory work for the FCTC and not until October 2000 that the first meeting of the Inter-governmental Negotiating Body - the body that drafted the FCTC—-was held.

${ }^{101}$ Interview with Hasbullah Thabrany, Jakarta, August 2014.

${ }^{102}$ Rosser and Wilson 2012; Aspinall 2014.
} 
a tension with the government's lax stance vis-à-vis tobacco control because, as current Health Minister Nafsiah Mboi acknowledged recently, 'the coverage paid for Jamkesmas is mostly for diseases related to smoking'. ${ }^{103}$ The national government's public response to this tension has been to threaten to exclude smokers from health coverage. ${ }^{104}$ But, as we have seen, it has also moved to toughen its tobacco control policies through the 2009 Health Law and Government Regulation 109/2012. It seems likely that concerns about the high cost of tobacco related illness for government health insurance schemes was a factor in this shift.

To be sure, Yudhoyono did not publically declare his hand in relation to tobacco control. In late 2013, Mboi told the media that Yudhoyono favoured ratification of the FCTC after she met him to discuss the matter. ${ }^{105}$ But his staff subsequently denied that his mind was made up and indicated that he was weighing the health benefits against the economic cost, in particular to tobacco farmers. ${ }^{106}$ His political party, the Democrat Party, was no clearer in its stance, with different figures taking quite contrary positions on the need for stricter tobacco controls. ${ }^{107}$ However, it seems fair to conclude that tobacco control was a much less straightforward political issue for Yudhoyono than it was for Wahid or Sukarnoputri. For them, tobacco control entailed no political benefits and significant political costs-a likely loss of electoral support in tobacco growing areas, reduced financial support from tobacco companies, and a potential threat to the government's fiscal position by virtue of its impact on government tax revenues. For Yudhoyono, however, these costs were offset (at least to some extent) by the likely positive impact of reduced tobacco consumption on the financial sustainability of the government's health insurance schemes and these schemes' popularity within the electorate. The upshot was a slightly greater receptiveness on the part of the government to introduce tobacco control reforms even if this was still constrained by tobacco companies' power.

\section{Conclusion}

In this article, I have examined the way in which political factors have shaped the nature of Indonesia's tobacco control policies during the post-New Order period. I have argued that there has been a noticeable but limited change in these policies, producing a policy regime

\footnotetext{
${ }^{103}$ Natahadibrata 2013. Similar concerns are believed to be behind Jakarta Deputy Governor Basuki Tjahaja Purnama's threat in early 2013 to deny smokers free health care under the Healthy Jakarta program. Interview with researchers at SMERU, Jakarta, November 2013. See also Putri 2013b.

104 Natahadibrata 2013.

105 Putri 2013a.

${ }^{106}$ Mulyana 2013; Hermawan 2014.

${ }^{107}$ Poskotanews.com 2013; DPRD Jatim Online 2014.
} 
that is simultaneously stronger than during the New Order period but still lenient by FCTC standards. I have pointed to the effects of two political factors in explaining this pattern of reform. First, tobacco companies and tobacco farmers have continued to exercise the dominant influence over policy by virtue of their economic power, strong political connections, organisational capacity, ability to mobilise popular forces, and deep engagement in the social and cultural life of the country. Second, TCAs have had greater capacity to participate in the related policy-making process because of the emergence of accessible new 'policy spaces' and increased state responsiveness to their concerns as a result of democratisation. While tobacco companies and tobacco farmers have remained the dominant influence over policy, these two developments have tilted the balance of power slightly in TCAs' direction.

As such, my analysis suggests that we need a more nuanced understanding of Indonesia's political economy than provided in accounts that emphasize continuity in the power of politico-bureaucratic, corporate and criminal interests nurtured under the New Order. While corporate interests have remained the dominant influence on Indonesia's tobacco control policies in the post-New Order period, other actors-most notably TCAs and tobacco farmers-have also played a role in shaping these policies. Ignoring their role risks an incomplete and potentially misleading analysis. To fully understand the nature of postNew Order politics we need to consider the role of these actors alongside the continued dominance of the various predatory elements who were nurtured during the New Order period.

Likewise, my analysis suggests a need to reconsider our understanding of the politics of tobacco control in developing countries and the prospects for promoting reform. It may be that, as much of the existing literature on the politics of tobacco control in developing countries suggests, the general picture with regards to the foreseeable future is bleak. But this does not mean that some wins cannot be achieved. In this respect, I suggest a need to give greater attention to the role of domestic TCAs in policy-making and the effect of democratization in shaping prospects for them to exercise influence. In terms of strategy, I indicate that support for such actors can have important pay-offs, particularly when they are operating under institutional conditions characterized by emerging policy spaces and changing electoral incentives.

With regards to the future of tobacco control policy in Indonesia, my analysis suggests that things are uncertain and contingent upon an ongoing process of struggle. As noted above, the tobacco companies are currently pushing for the enactment of a new 
Tobacco Law that is likely to undermine some of the tobacco control reforms introduced over the past few years. They also continue to oppose government ratification of the FCTC. But while TCAs have a relatively weak position in these struggles, they are no longer completely powerless thanks to changes wrought by democratization. It is possible that the political tide has finally changed in their favor, even if it is presently moving slowly. In early May 2014, PT HM Sampoerna issued a press statement saying that 2014 would be 'full of challenges' because of greater competition and the implementation of new tobacco control policies. There is also some evidence that investors are becoming increasingly cautious about investing in Indonesian tobacco stocks because of the potential effects of tougher tobacco control measures. ${ }^{108}$

Such developments leave TCAs a long way from being able to declare victory in the struggle for tobacco control. But they do offer some hope for the future.

\section{References}

Abadi, Tulus. 2008. Ayo “menyembah" industri rokok [Let's “worship” the cigarette industry]. Available at indotc1.blogspot.com.au/2008_01_01_archive.html (accessed 18 March 2014).

Achadi, Anhari, Widyastuti Soerojo, and Sarah Barber. 2005. The relevance and prospects of advancing tobacco control in Indonesia. Health Policy 72: 333-349.

Aditjondro, George. 2010. Membongkar gurita Cikeas di balik skandal Bank Century [Uncovering the Cikeas octopus behind the Bank Century scandal]. Yogyakarta: Galang Press.

Ahsan, Abdillah, Titissari, Ulysses Dorotheo, Raphaella Prugsamatz, Jennie Lyn Reyes. 2010. Indonesia: Tobacco tax report card. Bangkok: Southeast Asia Tobacco Control Alliance.

Antlöv, Hans, Rustam Ibrahim, and Peter van Tuijl. 2006. NGO governance and accountability in Indonesia: Challenges in a newly democratizing country. In Lisa Jordan and

${ }^{108}$ Rosser 2014. 
Peter Van Tuijl, eds., NGO Accountability: Politics, principles and innovation. London: Earthscan, 147-162.

Aritonang, Margareth. 2012. Anti-smoking groups protest House's planned tobacco bill. Jakarta Post, 14 December, 1.

Asian Forum of Parliamentarians on Population and Development. nd. Southeast Asia. Available at www.afppd.org/national-parliamentary-groups/southeast-asia/ (accessed 21 August 2014).

Aspinall, Edward. 2013. Popular agency and interests in Indonesia’s democratic transition and consolidation. Indonesia 96: 101-121.

Aspinall, Edward. 2014. Health care and democratization in Indonesia. Democratization 21 (5): 803-823.

Barber, Sarah, Sri Moertiningsih Adioetomo, Abdillah Ahsan and Diahhadi Setyonaluri. 2008. Tobacco economics in Indonesia. Paris: International Union Against Tuberculosis and Lung Disease.

Barraclough, Simon. 1999. Women and tobacco in Indonesia. Tobacco Control 8: 327-332.

Bloomberg Initiative. nd. What we fund. Available at tobaccocontrolgrants.org/Pages/40/What-wefund?who_region=SEARO\&country_id=39\&amount=\&date_type=\&date_from $=\&$ date_to $=$ \&viewall=View + All (accessed 14 March 2014).

Brock, Karen, Andrea Cornwall and John Gaventa. 2001. Power, knowledge and political spaces in the framing of poverty policy, IDS Working Paper 143, Brighton: Institute of Development Studies.

Bump, Jesse and Michael Reich. 2013. Political economy analysis for tobacco control in lowand middle-income countries. Health Policy and Planning 28: 123-133. 
Cairney, Paul, Donley Studlar, and Hadii Mamudu. 2012. Global tobacco control: Power, policy, governance and transfer. Houndmills: Palgrave Macmillan.

Chamim, Mardiyah. 2011. Epilog: devide et impera di zaman millennium [Epilogue: Divide and Rule in the Millennium Era]. In Mardiyah Chamim, Wahyu Dhyatmika, Farid Gaban and others. A giant pack of lies: Bongkah raksasa kebohongan: Menyorot kedigdayaan industri rokok di Indonesia [A giant pack of lies: Scrutinizing the might of the cigarette industry in Indonesia]. Jakarta: Koji Communications and Tempo Institute, 173-181.

Chamim, Mardiyah, Wahyu Dhyatmika, Farid Gaban and others. 2011. A giant pack of lies: Bongkah raksasa kebohongan: Menyorot kedigdayaan industri rokok di Indonesia [A giant pack of lies: Scrutinizing the might of the cigarette industry in Indonesia]. Jakarta: Koji Communications and Tempo Institute.

Chorev, Nitsan. 2013. Restructuring neoliberalism at the World Health Organization. Review of International Political Economy 20 (4): 627-666.

Datta, Indraneel. 2002. Parliamentary politics in Soeharto's Indonesia 1987-1998, unpublished PhD dissertation, School of Oriental and Asian Studies, University of London.

Dewan Perwakilan Rakyat. 2007. Laporan singkat rancangan Undang-Undang tentang kesehatan [Brief report of the draft law on health]. 19 November.

Dhyatmika, Wahyu. 2011. Hamparan bukti di lapangan [Breadth of evidence in the field]. In Mardiyah Chamim, Wahyu Dhyatmika, Farid Gaban and others, A giant pack of lies: Bongkah raksasa kebohongan: Menyorot kedigdayaan industri rokok di Indonesia [A giant pack of lies: Scrutinizing the might of the cigarette industry in Indonesia]. Jakarta: Koji Communications and Tempo Institute, 153-170.

Dick, Howard. 2008. The 2008 shipping law: Deregulation or reregulation? Bulletin of Indonesian Economic Studies 44 (3): 383-406. 
DPRD Jatim Online. 2014. Aksesi FCTC, rugikan petani tembakau [FCTC accession will harm tobacco farmers]. Available at dprd.jatimprov.go.id/berita/id/3123/aksesi-fctc-rugikanpetani-tembakau (accessed 9 March 2014).

Dressel, Bjorn and Marcus Mietzner. 2012. A tale of two courts: The judicialization of electoral politics in Asia. Governance 25 (3): 391-414.

Eriksen, Michael, Judith Mackay, and Hana Ross. 2014. The tobacco atlas, Atlanta, GA: American Cancer Society; New York: World Lung Foundation.

GAPPRI. 2000. Position paper on the proposed Framework Convention on Tobacco Control of the World Health Organization. Available at whqlibdoc.who.int/mnh/tobac_conv/F4690462.pdf (accessed 8 March 2014).

Gatot. 2007. Gugatan citizen law suit terhadap kebijakan ujian nasional [Citizen law suit on the national exam policy]. In Irianto Ridho (ed.) Menggugat ujian nasional [Against the national exam]. Jakarta: Teraju, 101-116.

Gresnews. 2011. YLKI gugat pemerintah dan DPR ratifikasi konvensi tembakau [YLKI sues the government and DPR over ratification of the tobacco convention], 3 Oktober. Available at: $\quad$ www.gresnews.com/berita/hukum/1548310-ylki-gugat-pemerintah-dan-dpr-ratifikasikonvensi-tembakau (accessed 15 March 2014).

Guindon, G. Emmanuel, Anne-Marie Perucic, and David Boisclair. 2003. Higher tobacco prices and taxes in South-east Asia, Health, Nutrition and Population Discussion Paper, Washington DC: World Bank.

Gunanto, E.S. and Mahbub Junaidy. 2010. Rokok haram, rokok makruh [Cigarettes are haram, cigarettes are makruh]. Tempo, 28 March, 94.

Hadiz, Vedi. 2003. Reorganizing political power in Indonesia: A reconsideration of so-called ‘democratic transitions’. Pacific Review 16 (4): 591-611. 
Hadiz, Vedi and Richard Robison. 2005. Neoliberal reforms and illiberal consolidations: The case of Indonesia. Journal of Development Studies 41 (2): 220-241.

Hadiz, Vedi. 2010. Localising power in post-authoritarian Indonesia: A Southeast Asian perspective. Stanford: Stanford University Press.

Hanafiah, Laksmiati. 2011. Para pemimpin kita sudah terbelenggu [Our leaders are chained]. In Mardiyah Chamim, Wahyu Dhyatmika, Farid Gaban and others, A giant pack of lies: Bongkah raksasa kebohongan: Menyorot kedigdayaan industri rokok di Indonesia [A giant pack of lies: Scrutinizing the might of the cigarette industry in Indonesia]. Jakarta: Koji Communications and Tempo Institute, 77-82.

Harian Terbit. 2013. Ratifikasi pengendalian tembakau dicurigai suarakan kepentingan asing [Tobacco control ratification suspected of expressing foreign interests]. 26 December. Available at harianterbit.com/2013/12/26/ratifikasi-pengendalian-tembakau-dicurigaisuarakan-kepentingan-asing/ (accessed 21 March 2014).

Hariyanti, Susi Dwi and Tim Lindsey. 2006. Indonesia: General elections test the amended Constitution and the new Constitutional Court. International Journal of Constitutional Law 4 (1): 138-150.

Harsono, Andreas. 2011. Public health suffers as Indonesia ignores calls for tobacco reform. Available at www.icij.org/node/28/public-health-suffers-indonesia-ignores-calls-tobaccoreform (accessed 24 August 2014).

Hermawan, Bayu. 2014. Istana: Belum ada putusan apapun soal FCTC [Palace: No decision whatsoever yet on FCTC]. Inilah.com, 27 February. Available at nasional.inilah.com/read/detail/2077986/istana-belum-ada-putusan-apapun-soal-fctc (accessed 22 March 2014).

Hidayat, Bagja, Wayan Agus and Pingit Aria. 2013. Rancangan galau pasal tembakau [Indecisive draft of tobacco article]. Tempo, 20 January, 38-39. 
Hurt, Richard, Jon Ebbert, Anhari Achadi and Ivana Croghan. 2012. Roadmap to a tobacco epidemic: Transnational tobacco companies invade Indonesia. Tobacco Control 21: 306-312.

Indonesia Corruption Watch. nd. Sejarah RUU terkait produk tembakau/Rokok [History of the draft law on cigarettes/tobacco products]. mimeo.

Indonesian Consumers Foundation. 1996. Advokasi konsumen: Asuhan Yayasan Lembaga Konsumen Indonesia: Ketegasan mengambil sikap [Consumer advocacy: Support from Indonesian Consumer Foundation: Determination to take a stand]. Kompas, 6 June, 18.

Jakarta Globe. 2012. Indonesian tobacco farmers protest anti-smoking regulation. 3 July.

Jakarta Post. 1995. Smoking costs a lot more than people think-Sujudi. 1 June.

Jakarta Post. 1996. RI condemns smoking cautiously. 1 June, 1.

Jakarta Post. 1997. Govt calls for no-smoking public places. 28 May.

Jakarta Post. 2007. Big tobacco ‘belittles’ Indonesia. 28 February.

Jakarta Post. 2009. Special report: Who's trying to kill the tobacco bill? 5 August, 10.

Jarvis, Darryl. 2012. The regulatory state in developing countries: Can it exist and do we want it? The case of the Indonesian power sector. Journal of Contemporary Asia 42 (3): 464492.

Khamdi, Muhammad. 2014. SBY diminta segera ratifikasi FCTC [SBY asked to ratify FCTC soon], Solopos.com, 4 February. Available at www.solopos.com/2014/02/04/sby-dimintasegera-ratifikasi-fctc-486940?mobile_switch=mobile (accessed 8 March 2014).

Kinasih, Herjuno. 2011. Faktor-faktor yang membentuk motivasi pekerja dalam organisasi pelayanan non-profit [Factors determining workers' motivations in a non-profit organisation], unpublished Masters of Social Welfare dissertation, University of Indonesia. 
Kompas. 1984. Penyakit kanker bukan bawaan-YKI beri resep waspada [Cancer is not a congenital disease-YKI advises awareness]. 2 September, 12.

Kompas. 1987. Menteri KLH: Tiga cara untuk menghadapi rokok [Environment minister: Three ways to address smoking]. 29 July, 13.

Kompas. 1989. Pencegahan primer penyakit kanker perlu ditingkatkan melalui KIE [Primary prevention of cancer needs to be increased through KIE]. 25 September, 6.

Kompas. 1991a. Rokok akan diberi label peringatan [Cigarettes to have warning label]. 21 January, 6.

Kompas. 1991b. Hari Tanpa Tembakau Sedunia tanggal 31 Mei [World No Tobacco Day 31 May], 24 May, p.12.

Kompas. 1996. Cantik tanpa tembakau [Beautiful without tobacco]. 21 April, 17.

Kompas. 2002. LSM mengugat media dan produsen rokok [NGO takes the media and cigarette producers to court]. 7 June, 10.

Kurniawati, Dewi and Anita Rachman. 2010. Big tobacco’s big influence keeps Indonesia lighting up, Jakarta Globe, 2 November. Available at www.thejakartaglobe.com/archive/bigtobaccos-big-influence-keeps-indonesia-lighting-up/ (accessed 26 August 2014).

Lawrence, S and J Collin. 2004. Competing with kreteks: Transnational tobacco companies, globalisation, and Indonesia. Tobacco Control 13 (Supp II): ii96-ii103.

Mahkamah Konstitusi. 2009. Putusan nomor 6/PUU-VII/2009 [Decision Number 6/PUUVII/2009]. Jakarta: Mahkamah Konstitusi.

Mahkamah Konstitusi. 2011a. Putusan nomor 19/PUU-VIII/2010 [Decision Number 19/PUU-VIII/2010]. Jakarta: Mahkamah Konstitusi. 
Mahkamah Konstitusi. 2011b. Putusan nomor 34/PUU-VIII/2010 [Decision Number 34/PUU-VIII/2010]. Jakarta: Mahkamah Konstitusi.

Mahkamah Konstitusi. 2012. Putusan nomor 57/PUU-IX/2011 [Decision Number 57/PUUIX/2011]. Jakarta: Mahkamah Konstitusi.

Mietzner, Marcus. 2009. Indonesia's 2009 elections: Populism, dynasties and the consolidation of the party system. Sydney: Lowy Institute.

Mietzner, Marcus. 2010. Political conflict resolution and democratic consolidation in Indonesia: The role of the Constitutional Court. Journal of East Asian Studies, 10: 397-424.

Mietzner, Marcus. 2013. Fighting the hellhounds: Pro-democracy activists and party politics in post-Suharto Indonesia. Journal of Contemporary Asia 43 (1): 28-50.

Ministry of Health. 2011. Masalah merokok di Indonesia [The smoking problem in Indonesia]. Available at www.promkes.depkes.go.id/index.php/topik-kesehatan/94pengendalian-rokok/26-pengendalian-masalah-rokok-di-indonesia (accessed 22 March 2014).

Mulyana, Ade. 2013. Istana: Pemerintah berhati-hati soal ratifikasi FCTC [Palace: Government cautious regarding FCTC ratification], 24 November. Available at politik.rmol.co/read/2013/11/24/134399/Istana:-Pemerintah-Berhati-hati-Soal-RatifikasiFCTC- (accessed 23 August 2014).

Natahadibrata, Nadya. 2013. Smokers could miss out on healthcare reform. Jakarta Post, 4 November.

Nugroho, ID. 2008. Tobacco farmers urge MUI to reject anti-smoking edict. Jakarta Post, 1 September: 8.

Pompe, Sebastian. 2005. The Indonesian Supreme Court: A study of institutional collapse. Ithaca: Cornell Southeast Asia Program Publications. 
Poskotanews.com. 2013. Pemerintah harus ratifikasi FCTC [Government must ratify FCTC]. 30 January. Available at poskotanews.com/2013/01/30/pemerintah-harus-ratifikasi-fctc/ (accessed 9 March 2014).

PT Data Consult Inc. 2009. Sampoerna Group company profile. Indonesian Commercial Newsletter, 1 November.

Putri, Tri Artining. 2013a. Menkes: Presiden dukung ratikikasi FCTC [Health minister: President supports FCTC ratification]. Tempo.co. Available at www.tempo.co/read/news/2013/08/16/173504823/Menkes-Presiden-Dukung-RatifikasiFCTC (accessed 9 March 2014).

Putri, Tri Artining. 2013b. Ahok ancam perokok tak bisa berobat gratis [Ahok threatens smokers will not get free health care]. Tempo.co. Available at www.tempo.co/read/news/2013/03/15/083467230/Ahok-Ancam-Perokok-Tak-Bisa-BerobatGratis (accessed 26 August 2014).

Republika Online. 2014. PKB minta Presiden tolak ratifikasi FCTC [PKB asks the President to reject FCTC ratification]. 27 Februari. Available at www.republika.co.id/berita/nasional/umum/14/02/27/n1n2m0-pkb-minta-presiden-tolakratifikasi-fctc (accessed 9 March 2014).

Reynolds, Catherine. 1998. Worshipping cancer sticks. Inside Indonesia, 56 (OctoberDecember).

Robison, Richard and Vedi Hadiz. 2004. Reorganising power in Indonesia: The politics of oligarchy in an age of markets. London: Routledge.

Rosser, Andrew. 2014. Challenging times for big tobacco. Inside Indonesia, 117. Available at www.insideindonesia.org/feature-editions/challenging-times-for-big-tobacco (accessed 20 August 2014).

Rosser, Andrew. Forthcoming. Law and the realisation of human rights: Insights from Indonesia’s education sector. Asian Studies Review. 
Rosser, Andrew and Jayne Curnow. 2014. Legal mobilisation and justice: Insights from the Constitutional Court case on international standard schools in Indonesia. The Asia-Pacific Journal of Anthropology 15 (4): 302-318.

Rosser, Andrew, Kurnya Roesad, and Donni Edwin. 2005. Indonesia: The politics of inclusion. Journal of Contemporary Asia, 35 (1): 53-77.

Rosser, Andrew and Ian Wilson. 2012. Democratic decentralisation and pro-poor policy reform in Indonesia: The politics of health insurance for the poor in Jembrana and Tabanan, Asian Journal of Social Science. 40 (5-6): 608-634.

Santosa, Mas Achmad. 2007. Class actions in Indonesia. Available at globalclassactions.stanford.edu/content/class-actions-indonesia (accessed 1 June 2013).

Schwarz, Adam. 1994. A nation in waiting: Indonesia in the 1990s. St Leonards: Allen and Unwin.

Sébrie, E.M., J Barnoya, E.J. Pérez-Stable, S.A. Glantz. 2005. Tobacco industry successfully prevented tobacco control legislation in Argentina. Tobacco Control 14 (5) (e2): 1-11.

Southeast Asia Tobacco Control Alliance. 2008. Tobacco industry tactics: A perfect deception: Corporate social responsibility activities in ASEAN. Bangkok: Southeast Asia Tobacco Control Alliance.

Stebbins, Kenyon. 1990. Transnational tobacco companies and health in underdeveloped countries: Recommendations for avoiding a smoking epidemic. Social Science and Medicine 30 (2): 227-235.

Stebbins, Kenyon. 2001. Going like gangbusters: Transnational tobacco companies "making a killing” in South America. Medical Anthropology Quarterly 15 (2): 147-170.

Straits Times. 1991. Campaigns hit Indonesia tobacco industry, 14 March. 
Studlar, Donley. 2002. Tobacco control: Comparative politics in the United States and Canada. Peterborough: Broadview Press.

Sumartono, Wasis, Anna Sirait, Mulyono Notosiswoyo, and Ratih Oemijati. 2012. The effectiveness of health education intervention to reduce high school students to smoke at the age of 20 Years. In Hasbullah Thabrany and Prih Sarnantio (eds.) Indonesia: The Heaven for Cigarette Companies and the Hell for the People. Jakarta: Center for Anti Smoking, University of Indonesia, 111-126.

Sumut Pos. 2010. Masyarakat Tembakau Indonesia dideklarasikan [Indonesian Tobacco Society launched]. 30 January. Available at www.hariansumutpos.com/arsip/?p=28467 (accessed 8 March 2014).

Tampubolon, Hans David. 2010. Do industry tentacles dictate tobacco control? Jakarta Post, 20 October, 4.

Tarmidi, Lepi. 1996. Changing structure and competition in the kretek cigarette industry. Bulletin of Indonesian Economic Studies 32 (3): 85-107.

Taufiq, Rohman. 2010. Soal fatwa rokok, MUI pilih jalan tengah [Cigarette fatwa issue: MUI chooses middle way]. Tempo Interaktif, 24 March.

Tempo. 2009. Lobi ayat di detik terakhir [Paragraph lobbying at the last moment]. 25 October: 42-43.

Tempo. 2010a. Dua coret ayat dua [Two delete paragraph two]. 28 March: 88-89.

Tempo. 2010b. Salah ketik atawa karena ketahuan [Mis-typed or because found out]. 10 October: 89-92.

Thabrany, Hasbullah and Prih Sarnantio, eds. 2012. Indonesia: The heaven for cigarette companies and the hell for the people. Jakarta: Center for Anti Smoking, University of Indonesia. 
Thoolen, Hans, ed. 1987. Indonesia and the rule of law: Twenty years of "New Order" government. London: Frances Pinter.

Tobacco Control Support Center-IAKMI. 2012. Fakta tembakau: Permasalahannya di Indonesia: Tahun 2012 [Tobacco facts: Issues in Indonesia: 2012]. Jakarta: TCSC and IAKMI.

Ulum, Fathul. 2010. Merokok hukumnya haram [Smoking ruled haram]. Forum Keadilan, 28 March: 32-33.

Widiastuti, Retno. 1996. Rokok, iklan dan konsumen [Cigarattes, advertisements and consumers]. Kompas, 6 June: 8.

Winters, Jeffrey. 1996. Power in motion: Capital mobility and the Indonesian state. Ithaca: Cornell University Press.

Winters, Jeffrey. 2010. Oligarchy. Ithaca: Cornell University Press.

World Bank. 1999. Curbing the epidemic: Governments and economics of tobacco control. Washington DC: World Bank.

World Bank. 2000. Indonesia: Curbing the tobacco epidemic. Available at siteresources.worldbank.org/INTPH/Resources/Indonesi_a.pdf (accessed 7 March 2014).

World Health Organization. 2012. Global adult tobacco survey: Indonesia report 2011. New Delhi: WHO Regional Office for Southeast Asia.

Ziegenhain, Patrick. 2008. The Indonesian parliament and democratization. Singapore: Institute of Southeast Asian Studies. 


\section{University Library}

\section{- M M I N E R VA A gateway to Melbourne's research publications}

Minerva Access is the Institutional Repository of The University of Melbourne

Author/s:

Rosser, A

Title:

Contesting Tobacco-Control Policy in Indonesia

Date:

2015-01-02

Citation:

Rosser, A. (2015). Contesting Tobacco-Control Policy in Indonesia. CRITICAL ASIAN STUDIES, 47 (1), pp.69-93. https://doi.org/10.1080/14672715.2015.997083.

Persistent Link:

http://hdl.handle.net/11343/127218 